\title{
PHYTOCHEMICAL SCREENING AND VOLATILE COMPOUND ANALYSIS USING GC-MS OF ISEM KEMBANG (Mangifera lampungise), INDIGENOUS FRUIT FROM LAMPUNG, INDONESIA
}

\author{
C. Irawan ${ }^{1}$, Hanafi $^{2}$, L. Sulistiawaty ${ }^{1}$, Foliatini $^{1, \varpi}$, H. Rochaeni ${ }^{1}$ \\ and M. Sukiman ${ }^{3}$ \\ ${ }^{1}$ Department of Chemical Analysis, Polytechnic of AKA Bogor, Bogor 16154, Indonesia \\ ${ }^{2}$ Department of Quality Assurance of Food Industry, Polytechnic of AKA Bogor, \\ Bogor 16154, Indonesia \\ ${ }^{3}$ Department of Industrial Waste Treatment, Polytechnic of AKA Bogor, \\ Bogor 16154, Indonesia \\ Corresponding Author: foliatini@gmail.com
}

\begin{abstract}
The study of volatile phytochemical compounds in the extract of "Isem Kembang (Mangifera lampungise)" fruits have been successfully conducted by using phytochemical assay, followed by Gas-Chromatography-Mass Spectrometry (GC-MS) method. Isem Kembang fruits were extracted using $n$-hexane, ethyl acetate and methanol in the separated experiment. The result of the phytochemical assay of isem kembang extract revealed the presence of various phytochemical bioactive: tannin and phenol in $n$-hexane and methanolic extract, fa flavonoid in the methanolic extract, and terpenoid in ethyl acetate extract. GC-MS analysis provides more detailed information, i.e. the structure of the primary constituents of each extracts, which involves alkanes, alkenes, esters, carboxylates, phenolic, aromatic, dan aldehyde compounds. The antioxidant capacity of the extract was evaluated by DPPH radical method. $\mathrm{IC}_{50}$ was found to be 23,89 , and $1871 \mathrm{mg} / \mathrm{L}$ for ean xtract of ethyl acetate, methanol and $n$-hexane, respectively. According to the results, the extract of isem kembang could be a potential resource of natural antimicrobial, antioxidant, and antidiabetic agents.
\end{abstract}

Keywords: Isem Kembang (Mangifera lampungise), Phytochemical Assay, Gas-Chromatography-Mass Spectrometry, Antioxidant Capacity

RASĀYAN J. Chem., Vol. 14, No.1, 2021

\section{INTRODUCTION}

Indonesia with thousands of islands provides a myriad of rich biological resources, especially the tropical fruit and its supporting genetic components. ${ }^{1}$ Unfortunately, the abundance olargely species diversity and sources of native Indonesian germ plasm has not been optimally utilized. ${ }^{2}$ One of them is Isem Kembang (Mangifera lampungise), a rare fruit from Lampung, Indonesia. Isem kembang belongs to the genus Mangifera, family Anacardiaceae, although its scientific name in binomial nomenclature is still unresolved. Some locals (in Kotabumi, North Lampung) called it asam kumbang (Mangifera quadrifida Jack ex Roxb, however, whether it is the same species still needs to be determined. Isem Kembang fruit is traditionally used by Lampung people as a mixture of chili (seruit) since it gives a nice aroma and taste.

Isem kembang is also used traditionally for improving eye, stomach, and throat health and helps the immune system. However, the nutrient and phytochemical contents of isem kembang are still unexploited. ${ }^{3}$ To our knowledge, the phytochemical composition and volatile compounds of the Isem kembang fruit have never been reported. Gas Chromatography tandem with Mass Spectrometry (GCMS) has been proven to be an effective and accurate analysis of components existing in medicinal plants or natural products. In recent years GC-MS studies have been reported for the analysis of medicinal plants including the analysis of non polar compounds and volatile essential oil, lipids, fatty acids, alkaloids, terpenoids, steroids, glycosides, saponin, amino acids, aldehydes, esters and other phytoconstituents which existed in minor quantities. ${ }^{4-6}$ In this recent study, we performed extraction process using several solvents and volatile compound analysis of Isem Kembang fruit using GC-MS 
technique. The antioxidant capacity of each extract was also evaluated and discussed following the phytochemical compounds contained in the extracts. This research opened the new potential for optimizing large-scale manufacturing herbal supplements therapeutic systems.

\section{Material and Methods}

\section{EXPERIMENTAL}

Ripe Isem Kembang (Mangifera lampungise) fruits (Fig.-1A) were harvested from the local plant in Menggala-Lampung, Indonesia. Only fully ripe, unblemished fruits were selected for further evaluation. After collection, the fruits were pulped and placed in plastic bags, labeled and stored at $4^{\circ} \mathrm{C}$ before analysis. Dragendorff's reagent, Meyer's reagent, methanol, ethyl acetate, $n$-hexane, concentrated sulfuric acid, concentrated $\mathrm{HCl}$, ferric chloride hexahydrate $\left(\mathrm{FeCl}_{3} \cdot 6 \mathrm{H}_{2} \mathrm{O}\right)$, acetic acid anhydride, acetic acid glacial, chloroform was purchased from Merck. All chemicals used $\mathrm{n}$ the experiment was of analytical grade.

\section{General Procedure}

\section{Sample Extraction}

Sample preparation was done by maceration using several organic solvents. Isem Kembang fruits were peeled and separated between the skin and the fruit, then dried at room temperature. Briefly, a 56. 1709 gram of powdered Isem Kembang fruits were immersed in $5 \mathrm{~L}$ of $n$-hexane for 3 days, and then filtered. Filtrate resulted from the filtration was then evaporated until a dry sample was obtained. This step yields a raw extract of $n$-hexane. The residue from the first immersion was immersed again in $5 \mathrm{~L}$ ethyl acetate for 3 days, to obtain the raw extract of ethyl acetate. After the solution was then filtered and evaporated, the residue from this step was immersed in methanol for 3 days, resulted in raw methanolic extract. The maceration process was repeated several times to obtain clear extract solution. After the extraction was completed, the percentage yield of the extraction process was calculated for each extract. The percentage yield of the extract was determined using the dry weight of extract (a) and soaked samples material (b) using the formula: Percentage yield $(\%)=a / b \times 100$.

\section{Detection Method \\ Phytochemical Assay}

Phytochemical assay of $n$-hexane, ethyl acetate, and methanolic extract of Isem Kembang was performed using standard protocols, which have been reported in previous studies. ${ }^{7-9}$ The assay included several tests for alkaloid, tannin, saponin, flavonoid, phenolic, and terpenoid.

\section{Structural Elucidation of Each Fraction by GC-MS}

Samples of $n$-hexane, ethyl acetate, and methanol extracts were further analyzed by Gas Chromatography-Mass Spectrometry (GC-MS) to determine the species contained in the samples. The chemical components were identified by comparing their mass spectra with those recorded in the mass spectral library. GC-MS analysis was performed by using Agilent 7890A GC system, Agilent 5975C series VL MSD, capillary column type, the flow rate of $1 \mathrm{~mL} / \mathrm{min}$, helium as a carrier gas, constant flow model, injector temperature of $250^{\circ} \mathrm{C}$, injection volume of $2 \mathrm{uL}$ and split injection technique. The oven temperature was programmed from $40^{\circ} \mathrm{C}$ for 2 minutes, with a temperature increment rate of $10^{\circ} \mathrm{C} /$ minutes, ana $\mathrm{d}$ final temperature of $280^{\circ} \mathrm{C}$ for 2 minutes. The total running time of $\mathrm{GC}$ analysis was 30 minutes.

\section{Antioxidant Activity}

Antioxidant activity of extracts was resolved by monitoring radical scavenging activity using DPPH method described in the past with slight modifications ${ }^{10}$. Briefly, $1 \mathrm{~mL}$ of $0.5 \mathrm{mM}$ DPPH $(1,1-$ diphenyl-2-picryl-hydrazil) solution in methanol was pipetted and transferred to the vial. Different concentrations of samples were prepared separately to obtain 50,100, 250, 500 and $1000 \mathrm{mg} / \mathrm{L} \mathrm{DPPH}$ solution in methanol. Each solution was transferred to the vials containing $0.5 \mathrm{mM}$ DPPH solution in methanol, and diluted by adding methanol until the total volume of $5 \mathrm{~mL}$. The absorbance of DPPH solution was measured by UV-Vis spectrophotometer at a wavelength of $515 \mathrm{~nm}$. Monitoring of absorbance was done every 5 minutes for a total of 30 minutes. Antioxidant activity was assessed from the absorbance decrease of DPPH solution with increasing sample concentration. \% inhibition was calculated as below: 


$$
\% \text { inhibition }=\frac{A_{\text {blank }}-A_{\text {ext }}}{A_{\text {blank }}} \times 100
$$

in which $A_{b l a n k}$ is the absorption of the blank sample and $A_{\text {extrat }}$ is the absorption of the extract.

\section{RESULTS AND DISCUSSION}

"Isem Kembang" fruits and their extracts have an appearance as shown in (Figure 1). After maceration in $n$-hexane, ethyl acetate and methanol, the as-obtained extracts were then examined through several procedures. The first step is a preliminary phytochemical assay to qualitatively analyze the phytoconstituents in the extracts. The second step is performing GC-MS technique to analyze and predict the structure of volatile compounds.


Fig.-1: (A)Dried isem kembang (Mangifera lampungise) fruits, (B)Inner Part of Fruits, (C) An Extract of Fruits (from left to right: extracted by n-hexane, ethyl acetate, and methanol).

\section{Extraction Using n-hexane, Ethyl Acetate and Methanol}

Extraction of the isem kembang fruits was conducted using several solvents, i.e. $n$-hexane, ethyl acetate and methanol, as they represent nonpolar, semipolar and polar solvent, respectively. Previous studies reported that the biologically active phytoconstituents may have polarity from low to high, depend on their chemical structure. ${ }^{11-13}$

Extraction of isem kembang fruit by maceration technique in various solvents for several days yielded a bright yellow solution. After evaporation, the extracts were changed to be dark brown, as shown in Fig.-1C. The yields of the extraction were listed in Table-1. The highest yields were achieved for ethyl acetate extract, and the lowest yield was obtained for n-hexane extract.

Table-1: The Yields of isem kembang (Mangifera lampungise) Fruit Extracts (per 56,1709 g of Samples).

\begin{tabular}{c|c|c|c|c}
\hline Solvent & $\mathrm{W}_{0}(\mathrm{~g})$ & $\mathrm{W}_{1}(\mathrm{~g})$ & $\mathrm{W}_{1}-\mathrm{W}_{0}(\mathrm{~g})$ & $\%$ yield* \\
\hline n-hexane & 14,9059 & 14,9654 & 0,0595 & 0,11 \\
\hline Ethyl acetate & 14,5276 & 18,2185 & 3,6909 & 6,57 \\
\hline Methanol & 14,7418 & 17,4883 & 2,7465 & 4,89 \\
\hline
\end{tabular}

* \% Yield is calculated using the followed equation: $\left(\left(\mathrm{W}_{1}-\mathrm{W}_{0}\right) / 56,1709\right) \times 100 \%$

\section{Preliminary Phytochemical Assay}

The as-prepared n-hexane, ethyl acetate and methanolic extracts were all subjected to phytochemical assay using standard method to confirm the presence of bioactive compounds in those extracts. Phytochemical assay was widely known as preliminary method that successful to show various phytochemical content in parts of plants, such as alkaloids, flavonoids, tannin, phenols, saponins and terpenoids. ${ }^{14-16}$

Table-2 revealed the negative result of Meyer, Dragendorf and Wagner test for all extracts, indicated that the alkaloids were not present in the extracts. The same result was obtained for the saponin test. Flavonoids were present in the methanolic extract but were absent in both n-hexane and ethyl acetate extracts. Tannins and phenolic compounds content in the n-hexane extract were higher than that of methanolic extracts, but in the ethyl acetate, they were absent. Terpenoids were only found in the ethyl acetate extract.

Phenolic and flavonoid compounds have been found in parts of plants and many studies reported various biological activities that correspond to them, such as antioxidant, antimicrobial, anticancer, cardioprotective effect, and anti-inflammatory. ${ }^{17,18}$ Previous studies reported that the antioxidant ISEM KEMBANG (Mangifera lampungise) 
functions correspond to their free radical scavenging activities to decrease oxidative stress. ${ }^{18-}$ ${ }^{19}$ Flavonoid also able to promote the wound healing property which may be responsible for wound contraction and increased rate of epithelialization ${ }^{20}$, and related to controlling the release of reactive oxygen species and some biochemicals. ${ }^{21}$

Based on the result of the phytochemical assay, it can be predicted that the antioxidant capacity of the ethyl acetate and methanolic extract was higher than that of the n-hexane extract. However, this prediction must be confirmed by further analysis using a more quantitative and accurate method.

Table-2: Phytochemical Assay of An Extract of isem kembang (Mangifera lampungise) Fruit.

\begin{tabular}{c|c|c|c}
\hline \multirow{2}{*}{ Phytochemicals } & \multicolumn{3}{|c}{ Extracting Agent } \\
\cline { 2 - 4 } & \multirow{2}{*}{ n-Hexane } & Ethyl acetate & Methanol \\
\hline Alkaloids: - Meyer & - & - & - \\
\hline - Dragendorf & - & - & - \\
\hline - Wagner & - & - & - \\
\hline Flavonoids & - & - & + \\
\hline Tannins & +++ & - & + \\
\hline Phenols & +++ & - & - \\
\hline Saponins & - & - & - \\
\hline Terpenoids & - & + & \\
\hline
\end{tabular}

\section{GC-MS Analysis}

Gas Chromatography-Mass Spectrometry (GC-MS) is such an effective and informative tool for characterizing and elucidating phytochemical organic compounds, since the mass spectrometer detector provides molar mass and the prediction of the structure of each compound separated from the gas chromatography. The chromatogram and mass spectrum of isem kembang extracts were shown in Figs. -2 to 4 and the constituents in each extract were listed in Tables- 3 to 5 , for $n$-hexane, ethyl acetate, and methanolic extract, respectively.

38 compounds were found in $n$-hexane extract, 6 compounds were in ethyl acetate extract and only one compound was found in methanolic extract. The number of the compounds found in the n-hexane extracts was larger than that of the ethyl acetate and methanolic extract since the GC-MS analysis has limited to only volatile compounds, in which they have higher affinity to $n$-hexane than to ethyl acetate and methanol.

$n$-Hexane extract contained phenolic and alcoholic compounds, long chain hydrocarbon (alkane and alkene), aldehyde and ester, but the highest percentage of substances was obtained for long chain alkanes : cyclohexadecane, $n$-heptacosane, $n$-heneicosane, and 1-bromo-heptadecane. The presence of the phenolic compound in the n-hexane extract, i.e. 2,4-bis(1,1-dimethylethyl)-phenol, was in agreement with the results of the phytochemical assay, so did the flavonoids and terpenoids which were absent in the extract.

Compared to the long-chain alkanes, the percentage of the area of the phenolic compounds was lower, but the amount of each fraction, in this case, could not exactly be calculated since the standard was not subjected to the experiment. Thus, the peak with a high percent area in the chromatogram, does not necessarily indicate a high quantity in the extract, especially when compared with the quantity of the same substance in the other extracts.

Most studies did not explain the biological activities of long-chain alkanes separately. However, the mixture of these compounds with other substances with different polarities may act in synergistic effects as an antioxidant. This phenomenon has been reported by Marrufo, ${ }^{22}$ in which the high amount of hydrocarbons found in the essential oil of $M$. oleifera could have antioxidant and antifungal activity, and also contribute to inhibit the microbial DNA, in the presence of quercetin and luteolin.

Heneicosane is an alkane compound that has a linear-chain structure with 21 carbon atoms. This substance has a role as a pheromone, a plant metabolite and a volatile oil component. ${ }^{23}$ This alkane compound is also possessed antimicrobial activity against pathogenic microorganisms. ${ }^{24}$

Table-4 reveals that the ethyl acetate extract contains alkanes (Cyclohexadecane, Cyclotetracosane), alkenes (Cyclohexadecene), and carboxylic acids (1-Pentadecanecarboxylic acid, n-Octadecanoic acid, dan 3-nitro-1,2-Benzenedicarboxylic acid). Cyclotetracosane has been found to have an efficient $\alpha$-amylase inhibitory activity. ${ }^{25} 1$-pentadecanecarboxylic acid also has capacity in inhibiting both $\alpha$ amylase and $\alpha$-glucosidase. ${ }^{26}$ 
RASĀYAN J. Chem.

Vol. 14 | No. 1 |276-287| January - March | 2021

A large number of medicinal plants have already been studied for their antidiabetic properties. One of the effective approaches to reduce the post-prandial hyperglycaemia is by controlling blood sugar levels. This approach involves the inhibition of carbohydrate digesting enzymes, $\alpha$-amylase and $\alpha$ glucosidase. $\alpha$-Amylase catalyzes the hydrolysis of 1,4-glycosidic bond in polysaccharides while $\alpha$ glucosidase hydrolyses disaccharides to monosaccharides. Hence, inhibiting these enzymes, prevents glucose intake into the body and helps in reducing diabetes risk. ${ }^{27}$ Thus, the presence of cyclotetracosane in ethyl acetate extract showed high potential of the extract for developing novel herbal formulation for diabetic therapeutical system.

Table-3: GC-MS Analysis of $n$-Hexane Extract of isem kembang (Mangifera lampungise) Fruits.

\begin{tabular}{|c|c|c|c|c|c|}
\hline No & PeakNum & Constituents & $\begin{array}{l}\text { Retention Time } \\
(\mathrm{min})\end{array}$ & $\%$ Area & Quality \\
\hline 1 & 4 & Phenol, 2,4-bis(1,1-dimethylethyl) & 8.388 & 1.18 & 96 \\
\hline 2 & 5 & Z-8-Hexadecene & 9.307 & 0.77 & 95 \\
\hline 3 & 9 & Cyclohexadecane & 12.384 & 5.32 & 99 \\
\hline 4 & 10 & (3E)-3-Icocene & 12.532 & 0.15 & 96 \\
\hline 5 & 11 & Bicyclo[2,2,1]-hept-2-en-7-ylidene & 13.019 & 0.16 & 95 \\
\hline 6 & 12 & 1-Eicosene & 13.378 & 1.56 & 97 \\
\hline 7 & 14 & Heneicosane & 14.315 & 0.24 & 97 \\
\hline 8 & 15 & 1-Hexadecanol & 14.729 & 0.21 & 92 \\
\hline 9 & 16 & (Z)-2-Tridecenal & 15.170 & 1.67 & 90 \\
\hline 10 & 17 & 1,7,11-trimethyl-4-(1-methylethyl) & 15.528 & 0.13 & 92 \\
\hline 11 & 18 & n-tricosane & 16.052 & 0.77 & 96 \\
\hline 12 & 20 & 2-(octadecyloxy) & 16.548 & 0.92 & 91 \\
\hline 13 & 21 & N2-[(2,4-dichlorophenoxy)acetyl]- & 16.833 & 3.72 & 92 \\
\hline 14 & 22 & 1-Iodooctatetracontane & 17.127 & 1.41 & 91 \\
\hline 15 & 23 & Tridecane & 17.375 & 1.96 & 90 \\
\hline 16 & 24 & n-Heneicosane & 17.660 & 3.54 & 95 \\
\hline 17 & 25 & 2-Methyltricos-3-ene & 17.908 & 2.65 & 93 \\
\hline 18 & 26 & 2-Methyltricos-3-ene & 18.156 & 3.23 & 95 \\
\hline 19 & 27 & n-heptacosane & 18.432 & 5.87 & 95 \\
\hline 20 & 28 & 1-Iodooctatetracontane & 18.689 & 3.36 & 91 \\
\hline 21 & 29 & 2-Methyltricos-3-ene & 18.919 & 3.55 & 96 \\
\hline 22 & 30 & n-Heneicosane & 19.167 & 5.89 & 94 \\
\hline 23 & 32 & $\begin{array}{l}\text { 2-Tridecene, 1-bromo-2-chloro-1,1- } \\
\text { difluoro-, (Z)- }\end{array}$ & 19.627 & 3.29 & 91 \\
\hline 24 & 33 & 1-Bromoheptadecane & 19.866 & 6.64 & 93 \\
\hline 25 & 34 & n-nonacosane & 20.086 & 2.98 & 98 \\
\hline 26 & 35 & (3E)-3-pentacosene & 20.288 & 3.25 & 95 \\
\hline 27 & 36 & n-nonadecane & 20.527 & 4.32 & 98 \\
\hline 28 & 37 & 1-Iodooctatetracontane & 20.748 & 2.88 & 92 \\
\hline 29 & 39 & 3-ethyl-tetra-cosane & 21.364 & 1.82 & 91 \\
\hline 30 & 41 & n-Tricosane & 21.740 & 1.86 & 94 \\
\hline 31 & 42 & (3E)-3-Icosene & 22.025 & 2.16 & 93 \\
\hline 32 & 43 & 12-Methyltricosane & 22.329 & 1.07 & 95 \\
\hline
\end{tabular}


RASĀYAN J. Chem.

Vol. 14 | No. 1 |276-287| January - March | 2021

\begin{tabular}{c|c|c|c|c|c}
\hline 33 & 44 & 1-Iodooctatetracontane & 22.512 & 0.53 & 91 \\
\hline 34 & 45 & 1-Chloroheptacosane & 22.705 & 0.51 & 91 \\
\hline 35 & 46 & Butyl heptadecyl ester & 22.880 & 0.47 & 91 \\
\hline 36 & 47 & (Z)-9-Tricosene & 23.146 & 0.41 & 93 \\
\hline 37 & 48 & Sulfurous acid, 2-propyl tetradecyl ester & 23.422 & 0.17 & 91 \\
\hline 38 & 50 & $\begin{array}{c}\text { 1H-Inden-1-ol, 5,7-bis(2,2-dimethylpropyl)- } \\
\text { 2,3-dihydro-2,2,3-trimethyl- }\end{array}$ & 24.617 & 0.13 & 93 \\
\hline
\end{tabular}



Fig.-2: GC Chromatogram of $n$-Hexane Extract of isem kembang (Mangifera lampungise) Fruits.

Table-4: GC-MS Analysis of Ethyl Acetate Extract of isem kembang Fruits.

\begin{tabular}{c|c|c|c|c|c}
\hline No & PeakNum & Constituents & Retention Time (min) & $\%$ Area & Quality \\
\hline 1 & 4 & (9E)-9-Icosene & 11.393 & 0,89 & 93 \\
\hline 2 & 5 & Cyclohexadecane & 12.321 & 2,86 & 98 \\
\hline 3 & 6 & 1-Pentadecanecarboxylic acid & 13.543 & 12,25 & 93 \\
\hline 4 & 9 & $n$-Octadecanoic acid & 15.170 & 2,50 & 93 \\
\hline 5 & 10 & Cyclotetracosane & 16.741 & 0,74 & 99 \\
\hline 6 & 11 & 1,2-Benzenedicarboxylic acid, 3-nitro- & 17.908 & 3,63 & 91 \\
\hline
\end{tabular}

Previous literature reported that octadecanoic acid detected in Bryonopsis laciniosa fruit exhibit several activities including antioxidant, anticancer, and anti-inflammatory. ${ }^{28}$ Bobade ${ }^{29}$ showed in their research that extracts containing hexadecanoic acid and octadecanoid acid in their methyl ester form 
have antimicrobial and antifungal properties. Derivatives of the compound 1,2-benzene dicarboxylic acid, from stem bark extract of Spondias mombin (Linn), in a mixture of other phytochemicals, showed synergistic antimicrobial effect against E. coli, Bacillus subtilis and Aspergilus flavus. ${ }^{30}$

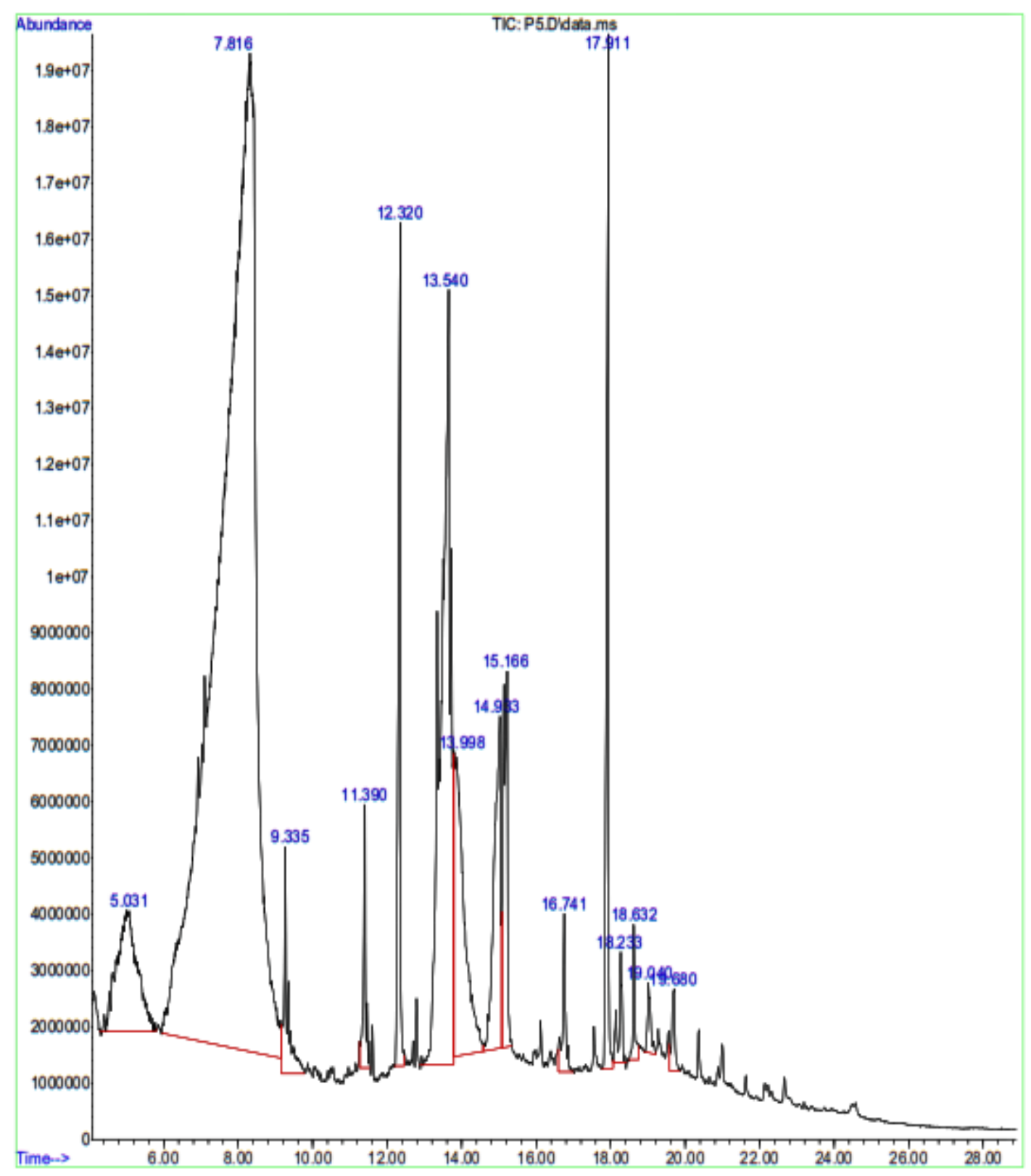

Fig.-3: GC Chromatogram of Ethyl Acetate Extract of isem kembang (Mangifera lampungise) Fruits.

The methanolic extract mostly contains derivate of aldehyde, i.e. 5-hydroxymethyl-2furancarboxaldehyde. 2-Furancarboxaldehyde also found in the extract of flower of buckwheat species, Fagopyrum tataricum, and contributes the antimicrobial activity of the extract. ${ }^{28}$ The furfural compound, i.e. 5-(hydroxymethyl) 2-furancarboxaldehyde, also shows antibacterial and antifungal activity applicable in pharmaceutical, cosmetics and pesticides. ${ }^{29}$ Furfural is used as a flavor in foods and other products, such as cosmetics, fragrance, pesticide, herbicide, fungicide, insecticide and germicide. ${ }^{30}$ Another derivate of furancarboxaldehyde, i.e. 5-(methyl) 2-furancarboxaldehyde also possess biological properties including significant antibacterial and antifungal effects. ${ }^{31}$

Table-5: GC-MS Analysis of Methanolic Extract of isem kembang Fruits.

\begin{tabular}{c|c|c|c|c|c}
\hline No. & PeakNum & Constituents & Retention Time (min) & $\%$ Area & Quality \\
\hline 1 & 2 & $\begin{array}{c}\text { 2-Furancarboxaldehyde, 5- } \\
\text { (hydroxymethyl)- }\end{array}$ & 5,787 & 78,88 & 90 \\
\hline
\end{tabular}




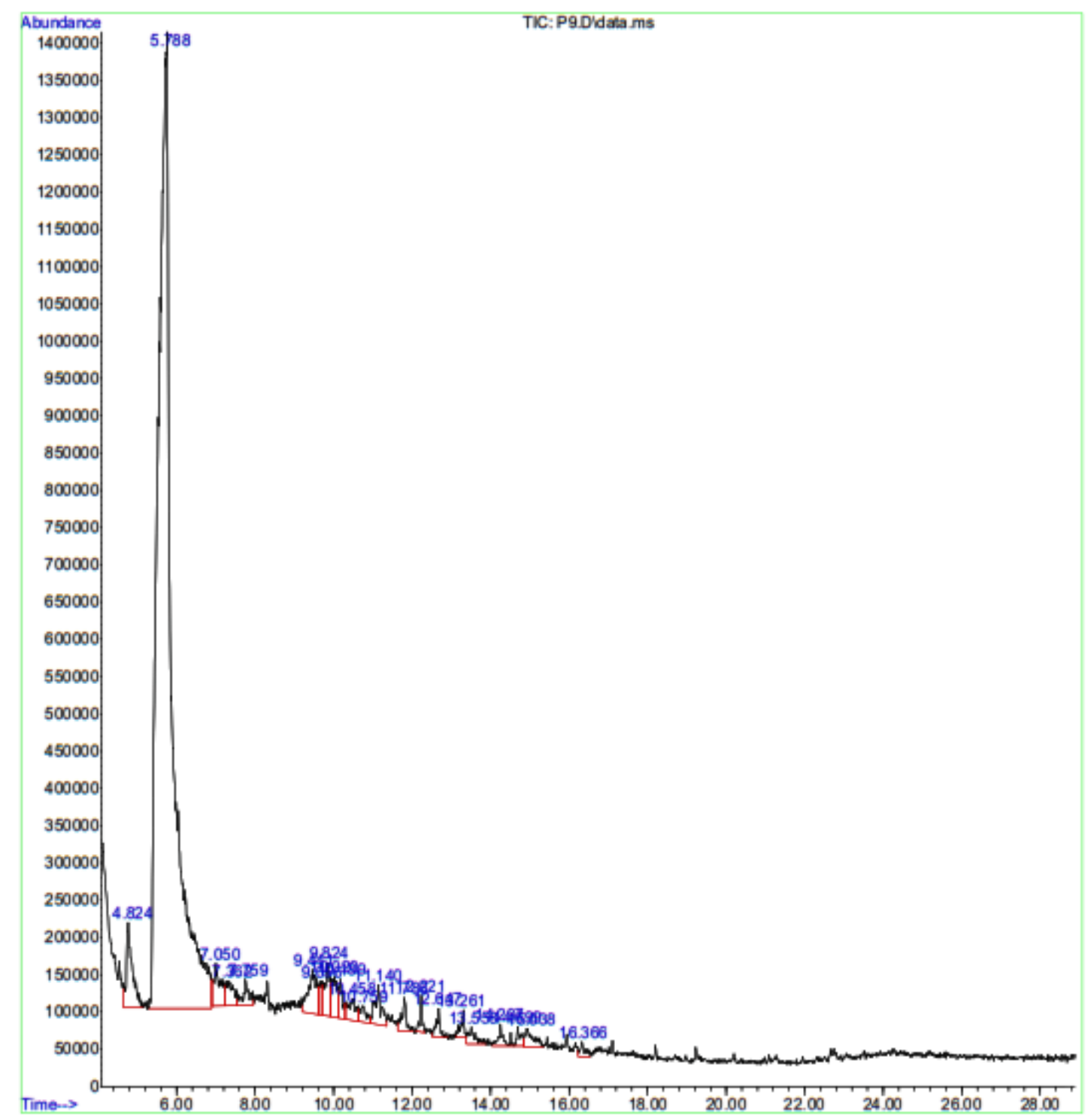

Fig.-4: GC Chromatogram of Methanol Extract of isem kembang (Mangifera lampungise) Fruits.

\section{Antioxidant of Extract}

The results of GC-MS analysis revealed that the all of isem kembang extract contains many phytochemical compounds that were the potential to have antimicrobial and antioxidant properties. Figure-5 showed the relationship between antioxidant capacity (in term of $\%$ inhibition) and extract concentration. The $\%$ inhibition of ethyl acetate extract increases drastically until the concentration of $100 \mathrm{mg} / \mathrm{L}$, and at higher concentration, the \% inhibition was relatively stable, indicated that the \% inhibition has reached the maximum value. For methanolic extract, at a concentration of $100 \mathrm{mg} / \mathrm{L}$, the $\%$ inhibition still increases and achieve the optimum value at a concentration of $500 \mathrm{mg} / \mathrm{L}$. A slight increment of \% inhibition was observed at concentrations larger than $500 \mathrm{mg} / \mathrm{L}$. A low \% inhibition was detected for $n$-hexane extract. At a concentration of $1000 \mathrm{mg} / \mathrm{L}$, the linear curve was still observed and appeared to maintain constant increment when the concentration was increased.

The scavenging effects of plant extracts on the DPPH radical were expressed as half minimum inhibitory concentration $\left(\mathrm{IC}_{50}\right)$ values. A lower $\mathrm{IC}_{50}$ value reflects higher $\mathrm{DPPH}$ radical scavenging activity. According to the results (Table-6), the ethyl acetate extract exhibited significant DPPH activity with the $\mathrm{IC}_{50}$ value of $22,99 \mathrm{mg} / \mathrm{L}$, the highest among the other extracts. The methanolic extract was the second-highest DPPH activity, with the $\mathrm{IC}_{50}$ of $89.26 \mathrm{mg} / \mathrm{L}$. However, the $n$-hexane extract showed very high $\mathrm{IC}_{50}$ or very low antioxidant activity. The previstudiestudy found that the $\mathrm{IC}_{50}$ was $67.82 \mathrm{mg} / \mathrm{L}$ for ethanolic extract of Mangifera indica leaves, ${ }^{32} 54.65,72.85,79.80,56.53$ $\mathrm{mg} / \mathrm{L}$ for ethanol, acetone, chloroform and petroleum ether extract of Mangifera indica fruit, 
respectively. ${ }^{33}$ Based on the result, the ethyl acetate extract of isem kembang (Mangifera lampungise) fruit has larger antioxidant activity than the ethanolic extract of Mangifera indica leaves and fruit.



Fig.-5: Percentage Inhibition of isem kembang Extract

Table-6: IC 50 of isem kembang Extract

\begin{tabular}{c|c|c|c|c}
\hline Extracting Solvent & $\begin{array}{c}\text { Extract } \\
\text { Concentration } \\
(\mathrm{mg} / \mathrm{L})\end{array}$ & Absorbance & \% Inhibition & $\mathrm{IC}_{50}(\mathrm{mg} / \mathrm{L})$ \\
\hline \multirow{5}{*}{ Ethyl acetate } & 50 & 0.4998 & 64 & \\
& 100 & 0.1305 & 91 & 22.99 \\
& 250 & 0.1004 & 93 & \\
\hline \multirow{5}{*}{ Methanol } & 500 & 0.0953 & 93 & \\
& 1000 & 0.0918 & 93 & \\
& 50 & 0.8515 & 45 & \\
& 100 & 0.7608 & 51 & \\
& 250 & 0.5081 & 67 & 1871.50 \\
& 500 & 0.1916 & 88 & \\
\hline
\end{tabular}

\section{CONCLUSION}

The result of the phytochemical assay of isem kembang extract revealed the presence of various phytochemical bioactives: tannin dan phenol in n-hexane and methanolic extract, a flavonoid in methanolic extract, and terpenoid in ethyl acetate extract. GC-MS analysis provided more detailed information, i.e. the structure of the primary constituents of each extract, which involves alkanes, alkenes, esters, carboxylates, phenolic, aromatic, dan aldehyde compounds. The result of the antioxidant assay revealed that the ethyl acetate and methanolic extract have the moderate antioxidant capacity, but the $n$-hexane extract has negligible antioxidant activity. These results suggested the extract of isem kembang fruits could be a potential resource of natural antioxidants that can be formulated as the main ingredient in the herbal supplement system. These fruits should also be further examined for their antimicrobial and antidiabetic activity.

\section{ACKNOWLEDGMENT}

The author thanks to Polytechnic of AKA Bogor for the financial support and also to Laboratory of Physics and Instrumentation, Polytechnic of AKA Bogor for providing the facilities. 


\section{REFERENCES}

1. C. Hermanto, N. L. P. Indriani and S. Hadiati, Keragaman dan Kekayaan Buah Tropika Nusantara, IAARD press, Jakarta, p.1 (2013)

2. T. Uji, Biodiversitas Journal of Biological Diversity, 8, 157(2007), DOI:10.13057/biodiv/ d080217

3. V. Vanitha and K. Manikandan, Rasayan Journal of Chemistry, 9, 471(2016)

4. O. Fadriyanti, I. D. Nasution, D. Handayani and W. Siswomiharjo, Rasayan Journal of Chemistry, 12, 04(2019), DOI:10.31788/RJC.2019.1245415

5. N. Z. Ismail, H. Arsad, M. R. Samian, and M. R. Hamdan, AGRIVITA Journal of Agricultural Science, 39(3), 335(2017), DOI:10.17503/agrivita.v39i3.1076

6. M. Jayalakshmi, V. Vanitha and R. Sangeetha, Asian Journal of Pharmaceutical and Clinical Research, 11, 1(2018), DOI:10.22159/ajpcr.2018.v11i10.26857

7. M. Manigandan and K. Kolanjinathan, Asian Journal of Pharmaceutical and Clinical Research., 9, 1(2016), DOI:10.22159/ajpcr.2016.v9s3.15759

8. A. Naz, M. Saeed, M. M. Hussain and M. S. Ishaq, Bangladesh Journal of Pharmacology, 10, 21(2015), DOI:10.3329/bjp.v10i1.20639

9. U. S. M. Rao, M. Abdurrazak and K. S. Mohd, Malaysian Journal of Analytical Sciences, 20, 1181(2016), DOI:10.17576/mjas-2016-2005-25

10. C. Irawan, Foliatini, Hanafi, L. Sulistiawaty and M. Sukiman, Pharmacognosy Journal, 10, 92(2018), DOI:10.5530/pj.2018.1.17

11. E. N. Sembiring, B. Elya and R. Sauriasari, Pharmacognosy Journal, 10, 123(2018), DOI:10.5530/ pj.2018.1.22

12. S. Felhi, A. Daoud, H. Hajlaoui, K. Mnafgui, N. Gharsallah and A. KADRI, Food Science and Technology, 37, 483(2017), DOI:10.1590/1678-457X.23516

13. H. Nawaz, M. A. Shad, N. Rehman, H. Andaleeb and N. Ullah, Brazilian Journal of Pharmaceutical Science, 56, (2020), DOI:10.1590/s2175-97902019000417129

14. A. Altemimi, N. Lakhssassi, A. Baharlouei, D. G. Watson and D. A. Lightfoot, Plants (Basel), 6, 42(2017), DOI:10.3390/plants6040042

15. R. S. Farag, M. S.Abdel-Latif, H. H. A. El Baky and L. S. Tawfeek, Biotechnology Reports, 28, 1(2020), DOI:10.1016/j.btre.2020.e00536

16. R. Gul, S.U. Jan, S. Faridullah, S. Sherani and N. Jahan, The Scientific World Journal, 2017, 1(2017), DOI:10.1155/2017/5873648

17. S. Kumar and A. K. Pandey, The Scientific World Journal, 2013, 1(2013), DOI:10.1155/2013/ 162750

18. D. Tungmunnithum, A. Thongboonyou, A. Pholboon, A. Yangsabai, Medicines (Basel), 5, 93(2018), DOI:10.3390/medicines5030093

19. E. Oskoueian, A. R. Omar, N. Abdullah, S. Ahmad, W. A. Saad and Y. W. Ho, International Journal of Molecular Sciences, 12, 5955 (2011), DOI:10.3390/ijms12095955

20. P. A. Ramanujam, S.K. Pandian and B. Abinaya, Biofouling, 30, 1111(2014), DOI:10.1080/08927014.2014.972386

21. M. S. Aslam, H. Riaz, S. A. Raza, M. S. Ahmad, 2018, Role of Flavonoids as Wound Healing Agent, In book: Phytochemicals, Intech Open, pp: 95-98, DOI:10.5772/intechopen.79179

22. T. Marrufo, F. Nazzaro, E. Mancini, F. Fratianni, R. Coppola, L. D. Martino, A. B. Agostinho and V. D. Feo, Molecules, 18, 10989 (2013), DOI:10.3390/molecules180910989

23. C. F. Funaro, K. Böröczky, E. L. Vargo and C. Schal, Proceedings of the National Academy of Sciences, 115, 15(2018), DOI:10.1073/pnas.1721419115

24. V. Vanitha,S. Vijayakumar, M. Nilavukkarasi, V. N. Punitha, E. Vidhya and P. K. Praseetha, Industrial Crops and Products, 154, 112748 (2020), DOI:10.1016/j.indcrop.2020.112748

25. U. D. K. Vijayamuthuramalingam, R. Rajaram, K. M. Kuppusamy, B. Jonnalagadda and S. Arokiasamy, Iranian Journal of Basic Medical Sciences, 20, 1390 (2017), DOI:10.22038/IJBMS.2017.9623

26. J. -Y. Yang, J. -H. Park, N. Chung and H. -S. Lee, Scientific Reports, 7, 1 (2017), DOI:10.1038/srep45746

27. P. Agarwhal and R. Gupta, Research and Reviews Journal of Medical and Health Sciences, 5, 1(2016)

28. B. Ramya, T. Malarvili and S. Velavan, International Journal of Pharmaceutical Sciences and Research, 6, 3375(2015), DOI:10.13040/IJPSR.0975-8232.6(8).3375-79

ISEM KEMBANG (Mangifera lampungise) 
29. A. F Bobade, Acta Scientific Pharmaceutical Sciences, 3, 8(2019), DOI:10.31080/ ASPS.2019.03.0412

30. O. T. Osuntokun and G. M. Cristina, International Journal of Molecular Biology: Open Access, 4, 135(2019), DOI:10.15406/ijmboa.2019.04.00110

31. J. Zhao, L. Jiang, X. Tang, L. Peng, X. Li, G. Zhao and L. Zhong, Molecules, 23, 182(2018), DOI:10.3390/molecules23010182

32. G. A. Subramenium, T. K. Swetha, P. M. Iyer, K. Balamurugan and S. K. Pandian, Microbiological Research, 207, 19(2018), DOI:10.1016/j.micres.2017.11.002

33. B. A. Ismail, D. A.Nassar, Z. H. A. El-Wahab, O. A. M. Ali, Journal of Molecular Structure, 1227, 129393(2021), DOI:10.1016/j.molstruc.2020.129393

34. G. J. Mohammed, M. J. Al-Jassani and I. H. Hameed, International Journal of Pharmacognosy and Phytochemical Research, 8, 480 (2016)

35. K. S. Dhital, Journal of Pharmacognosy and Phytochemistry, 6, 205 (2017)

36. V. A. Kamble, D. O. Somkuwar and S. J. Wankhade, International Current Pharmaceutical Journal, 5, 82(2016), DOI: 10.3329/icpj.v5i10.29523

[RJC-5674/2020] 